\title{
Collaboration Based Agroforestry Development Strategy in Laubonu Village, Atsabe Subdistrict, District Ermera, Timor Leste
}

\author{
Fernando Da Silva ${ }^{1}$ Muhammad Dassir $^{2}$ Mujetahid M. $^{3}$ S. Nadirah ${ }^{4}$ \\ ${ }^{1}$ Forestry Study Program, Graduate School Hasanuddin University, Makassar, 90245, Indonesia \\ ${ }^{2}$ Forestry Study Program, Graduate School Hasanuddin University, Makassar, 90245, Indonesia \\ ${ }^{3}$ Forestry Study Program, Graduate School Hasanuddin University, Makassar, 90245, Indonesia \\ ${ }^{4}$ Agriculture Faculty, Ichsan University Gorontalo, 96211, Indonesia
}

Corresponding Author: Fernando Da Silva. Forestry Study Program, Graduate School Hasanuddin University, Makassar, 90245, Indonesia E-mail: dasilvanando991@gmail.com

Received date: 28 August 2019, Accepted date: 14 December 2019, Online date: 20 December 2019

Copyright: (C) 2019 Fernando Da Silva et al., This is an open-access article distributed under the terms of the Creative Commons Attribution License, which permits unrestricted use, distribution, and reproduction in any medium, provided the original author and source are credited.

\begin{abstract}
The forest area of Timor-Leste $\pm \mathbf{8 6 9}, 130.41$ ha, representing $59 \%$ of the total land area of $1,493,130.41$ ha. Timor-Leste's forest area is classified as good forest cover $312,930.67$ ha and forest cover is less good 556,199.74 ha. The objective of this study is? (1) Identifying forest management problems in the village of Laubonu Timor Leste, and (2) Formulating a collaborative development based agroforestry strategy. The research was conducted from June 2019 to August 2019. The study population was stakeholders related to forestry development in Laubonu village. The number of respondents was 30 people. The data analysis method uses descriptive qualitative analysis. The results of the study show the general problems faced by most formal forestry and environmental institutions in Timor Leste, namely: (1). Lack of human resources and the low level of education of formal institutions. (2). Lack of synchronization - program integration in overcoming forest encroachment and illegal logging. (3). The absence of agroforestry models as an alternative to increase community income as well as improving the quality of forest area ecosystems to control landslides, forest fires, and critical land, and the absence of policies for the legality of forest area management rights for communities that have long encroached on forest areas. The Agroforestry Development Strategy that can be adopted by the Government of Timor Leste, namely the level of the Ministry of Forestry forms a Working Group (POKJA) for developing Agroforestry (PA). Its main tasks are (1) facilitating the development of regulations (policies and programs) for agroforestry development at pilot sites (2). Facilitating the implementation of the PA Development Program Strengthening Training and briefing for facilitators at the level of directors, district, sub-district and village staff who will socialize and as a facilitator in organizing the agroforestry development program. Facilitators at the district and sub-district, village and field levels are awareness / socialization, formation and strengthening of institutions and preparation of a technical plan for agroforestry development. The agroforestry development model that can be developed in Laubonu Village, which is the agrisilviculture model and the agrosilvopasture model Agrosilviculture model which is adaptive to drought and is able to meet the food needs of the population and can increase the income of the population as a source of weekly, seasonal and annual income, by continuing to plant seasonal crops such as peanuts and corn, and enriched with annual crops such as coffee, gamal, and mahogany, while the Agrosilvopasture model is expected to be a source of fodder for goats and cattle, besides there are weekly and seasonal income sources in the presence of coffee plants, while for seasonal and annual there is a product of goats and candlenuts. In the long run there is wood yield from mahogany stands.
\end{abstract}

Keywords: Collaboration-Based Forestry Development Strategy.

\section{INTRODUCTION}

Timor-Leste's forest area is $\pm 869,130.41$ ha, representing $59 \%$ of the total land area of Timor Leste, which is $1,493,130.41$ ha. Timor-Leste's forest area was classified into two parts, namely forests that have a good cover of $312,930.67$ ha and forest cover of less than 556,199.74 ha. [1]. Deforestation was caused by rainfall and topography systems, where $41 \%$ of the total area has slopes greater than 40\% (Mota, 2002). Timor Leste has 44 Protected Areas which have been determined based on UNTAET Regulation [2].

Forest fires, landslides, illegal logging and increasing critical land for cultivation activities such as planting crops is severely damaged. This causes the environment around the forest to be uninhabitable by the community because very prone to disasters.

Formal institutions that deal with forestry and environmental management programs have not been able to overcome these environmental problems. Due to the lack of synchronisation of programs between official institution levels from the central level to rural areas, the limited number of human resources, and the lack of collaborative management. 
[3] defines collaborative management as an approach in natural resource management that has many dimensions, combining various parties that have a role, with the final goal being environmental conservation, equitable distribution of benefits and responsibilities in natural resource management. Collaborative management can also be interpreted as a strategy in formulating long-term vision and goals to overcome social problems that occur, together with formulating cooperative programs and actions and allocating resources to carry out these action programs [4].

Forestry Development Strategy to improve community welfare and improve the quality of forest land-based Collaboration in Laubonu village should be a concern of many parties because the forest area is a joint responsibility between the central government of East Timor with regional governments (provincial and district) as well as village governments and local residents around the forest area so that the function of the forest area can be improved its role as a buffer for human life and also a place to preserve the diversity of plants and animals and their ecosystems.

\section{The formulation of the problem in this study are:}

1. What are the forest management problems in Laubonu Village?

2. What is the collaborative model for developing agroforestry as a strategy for dealing with forest destruction?

\section{The purpose of this research is}

1. Identify problems that occur in forest management in the village of Laubonu Timor Leste.

2. Formulate a collaborative forestry development strategy based on Laubonu village.

\section{RESEARCH METHODS}

This research was conducted in early June 2019 until August 2019. The population in this study were stakeholders involved in forestry development in laubonu village. The number of respondents in this study was 30 community respondents in Laubonu village, Atsabe District, Ermera District, Timor Leste State. The data analysis method uses descriptive qualitative analysis, in formulating a collaborative forestry development strategy in the Labonu Village of Timor Leste.

\section{RESULTS AND DISCUSSION}

\section{A. Forestry Problems in the Labonu Village of East Timor \\ 1. Use of Forest Areas}

The activities of utilizing forest areas by communities around forests include (1) farming activities, (2) breeding goats and buffalo are released (3) illegal logging, (4) hunting deer and (5) honey gatherer from natural bees. The impact of using the forest area by the local community called the occurrence of landslides, forest fires, and critical land. Increasing damage to forest areas needs to be anticipated with local community empowerment programs through collaborative forest management strategies and the development of agroforestry that is adaptive to the arid climatic conditions of the region.

\section{Agroforestry Patterns in Laubonu Village}

The people of Laubonu Village have traditionally carried out cultivation activities by planting annual crops, such as corn and peanuts in the forest area. This has an impact on the growing area of degraded land and people's incomes that tend to be stagnant (Table 1). Strategies that can be taken to overcome the negative impacts are the development of drought-resistant agroforestry with Agrosilvokulture and or Agrosilvopasture patterns.

Table 1. Agroforestry Patterns in Laubonu Village Communities

\begin{tabular}{|l|l|l|l|}
\hline No & Agroforestry Pattern & Planting Pattern & Impact \\
\hline 1 & Field & $\begin{array}{l}\text { Monoculture Corn } \\
\text { Monoculture Peanuts } \\
\text { Paddy fields }\end{array}$ & $\begin{array}{l}\text { - Increase in forest encroachment } \\
\text { - erosion } \\
\text { - Increased critical land }\end{array}$ \\
\hline 2 & $\begin{array}{l}\text { Large } \\
\text { farming }\end{array}$ & $\begin{array}{l}\text { a. goat, and / or buffalo } \\
\text { are released } \\
\text { b. Pig is grounded }\end{array}$ & $\begin{array}{l}\text { - Lack of animal feed } \\
\text { - It can't be on a large scale. } \\
\text { - The need for fence raw materials and a large allocation of labor } \\
\text { for the protection and security of field crops (corn, rice or peanuts) }\end{array}$ \\
\hline
\end{tabular}

\section{Institutional issues in forest management in Timor Leste.}

The Minister of Agriculture and Sea handles the institutional system for managing forest areas in the State of Timor Leste, namely the central government and subsequently delegated to the Directors of Forestry and Watershed Management. While at the Regency level, it is handled by the Head of the Forestry Service, at the District and Village level respectively by the chair of the Forestry Department and the Village Head. Common problems faced by most formal institutions dealing with forestry and the environment in Timor Leste, namely: (1)lack of human resources and the low level of education of formal institutions, (2) lack of synchronization - program integration in overcoming forest encroachment and illegal logging. The absence of agroforestry models as an alternative to increasing community income as well as improving the quality of forest 
ecosystems (Table 2), and the absence of policies for the legality of forest management rights for communities that have long encroached on forest areas.

\section{B. The foundation of collaborative development of agroforestry based in Laubonu Village \\ 1. Conflict resolution through alternative granting of rights to manage forest areas}

The results of field observations and interviews obtained information that the community enters the forest area doing field agroforestry activities to fulfil daily food sources from corn and rice. Dependence on these forest areas as agroforestry areas is very high, due to the absence of alternative land that can be managed to meet the daily subsistence needs of farmers encroaching the forest area. As a consequence of these conditions, it is necessary to provide alternative forest management rights. The mechanism for granting management rights is carried out in collaboration between formal institutions related vertically hierarchically from the Ministry to the village government with the criteria, as illustrated in Table 2.

Table 2. Scope of Community Rules and Criteria that can be granted Forest Management Rights

\begin{tabular}{|l|l|l|}
\hline No & Scope of Rules & Description \\
\hline 1. & $\begin{array}{l}\text { Granting of forest area } \\
\text { management rights. }\end{array}$ & $\begin{array}{l}\text { 1. Farmers who work in forest areas are people who have lived in the village } \\
\text { administration area for at least 10 years. } \\
\text { 2. Registered with the Village Institution as armer managing rights to the forest area. } \\
\text { 3. The period of granting forest management rights is } 30 \text { years and is evaluated every 5 } \\
\text { years. }\end{array}$ \\
\hline 2. & $\begin{array}{l}\text { It is not permitted to } \\
\text { transfer forest } \\
\text { management rights }\end{array}$ & $\begin{array}{l}\text { 1. Cultivating farmers are not allowed to transfer because forest management does not } \\
\text { constitute ownership of the forest area. } \\
\text { 2. Farmers who are known to transfer or pawn their management rights will be given } \\
\text { sanctions to terminate their management contracts. }\end{array}$ \\
\hline 3. & $\begin{array}{l}\text { Revocation/loss of forest } \\
\text { area management rights. The farmer died. } \\
\text { 2. It is known to change the function of the forest area. } \\
\text { 3. Disobeying forest management rules. } \\
\text { 4. No longer domiciled in the village administration area. } \\
\text { 5. Resign as a farmer working on forest management rights. }\end{array}$ \\
\hline
\end{tabular}

\section{Collaborative Development Model of Agroforestry}

Agroforestry Development Strategies that can be adopted by the Government of Timor Leste, namely at the Ministry of Forestry level form a Working Group (POKJA) for developing Agroforestry (PA). Its main tasks are (1) facilitating the development of regulations (policies and programs) for agroforestry development at pilot locations. At the same time, building cooperation with Forestry Multistakeholder donors to obtain grant support in facilitating the implementation of the Agroforestry Development Program in Laubonu, facilitating the implementation of the PA Development Training Stabilization Program and the provisioning of facilitators for staff at the directors, district, sub-district and village levels that will socialize and as a facilitator in organizing the agroforestry development program.

The main agenda of the work of the facilitators at the district and sub-district, village and field levels is awareness/socialization, the formation and strengthening of institutions and the preparation of a Technical Plan for the development of agroforestry. The Ministry of Forestry and Marine support funding needs for the implementation. Informing the institutional development of agroforestry at the village level, it is carried out through a democratic meeting of Laubonu villagers. While the implementation of preparing the Technical Plan is done using the PRA method.

The multistakeholder collaboration process at the village level, including the involvement of local and non-community community stakeholders (international NGOs and local NGOs) as field facilitators to overcome the limited number of employees at the district. In addition to sub-district and village levels, resulting in cooperation (cooperation) and ongoing information exchange. Also, modifying activities and sharing of resources for mutual benefit and to achieve shared goals. Collaboration is based on exchanges in networking and coordination by adding new behaviours, namely the willingness to share resources, and finding a focal point that is a common goal [5].

Facilitating the formation of institutions at the local level (groups or communities around the forest area by sub-district / village facilitators, namely the establishment of elements of group leaders, wherein the leaders recruit members of PA participants with mutually agreed criteria, namely; residing in villages in the PA Program location, preferably residents whose economies weak and have livelihood links in forest areas. 
Table 3. Collaborative Model of Agroforestry Development in Timor Leste's Labonu Village

\begin{tabular}{|c|c|c|c|}
\hline No. & The institution & $\begin{array}{c}\text { Agroforestry Development } \\
\text { Collaboration Model }\end{array}$ & Expected Impact \\
\hline 1. & $\begin{array}{l}\text { Director of Forestry and } \\
\text { Watershed Management }\end{array}$ & $\begin{array}{l}\text { 1. Form a central PA working group } \\
\text { (LWG) } \\
\text { 2. Facilitation of funding and NGO } \\
\text { networks. } \\
\text { 3. Make PA programs and policies }\end{array}$ & $\begin{array}{l}\text { 1. There are regulations to address conflict } \\
\text { resolution and forest management } \\
\text { programs for the economic and ecological } \\
\text { improvement of land. } \\
\text { 2. The formation of an institutional } \\
\text { platform for collaborative forest } \\
\text { management. }\end{array}$ \\
\hline 2. & $\begin{array}{l}\text { Collaboration between } \\
\text { the Director of Forestry } \\
\text { and Watershed } \\
\text { Management and the } \\
\text { Head of the Forest } \\
\text { Service. }\end{array}$ & $\begin{array}{l}\text { 1. Collaboration on the formation of } \\
\text { district, sub-district, village and field } \\
\text { facilitators. By the Pokja Team } \\
\text { 2. Briefing of the district, sub-district and } \\
\text { village level facilitators }\end{array}$ & $\begin{array}{l}\text { 1. A team of organizers to implement } \\
\text { awareness-raising and capacity building } \\
\text { for agroforestry developers is formed. } \\
\text { 2. Overcoming the limited number of } \\
\text { human resources }\end{array}$ \\
\hline 3. & $\begin{array}{l}\text { Kolaborasi Kepala Dinas } \\
\text { Kehutanan dan Ketua } \\
\text { Departemen Kehutanan. }\end{array}$ & $\begin{array}{l}\text { Facilitate the preparation of agroforestry } \\
\text { technical designs }\end{array}$ & $\begin{array}{l}\text { Adaptive agroforestry design according to } \\
\text { local conditions in selected village plots }\end{array}$ \\
\hline 4. & $\begin{array}{l}\text { Chairperson of the } \\
\text { Forestry Department in } \\
\text { Atsabe District and Head } \\
\text { of Laubonu Village. }\end{array}$ & $\begin{array}{l}\text { 1. Facilitator forming RA and PA } \\
\text { participant farmer groups } \\
\text { 2. Together with village facilitators to } \\
\text { assist, monitor and supervise the } \\
\text { implementation of RA and PA for } \\
\text { farmers participating in the RA and PA } \\
\text { program. }\end{array}$ & $\begin{array}{l}\text { 1. Forest area conflict resolution. } \\
\text { 2. Forest management models to deal with } \\
\text { forest damage (erosion, critical land, and } \\
\text { forest fires). }\end{array}$ \\
\hline 5. & $\begin{array}{l}\text { Laubonu Village Head } \\
\text { and community. }\end{array}$ & $\begin{array}{l}\text { Decentralization of the functional } \\
\text { development of the agroforestry model } \\
\text { (agriculture and agrosilvopasture) }\end{array}$ & $\begin{array}{l}\text { 1. resolution of conflicts and increased } \\
\text { participation of local people in forest } \\
\text { protection/security } \\
\text { 2. increasing farmers' food resilienc }\end{array}$ \\
\hline
\end{tabular}

Based on Table 3 above, the Collaboration on forestry development in East Timor with the setting of the Labonu Village case study was built through networking, coordination and cooperation. Institutional capacity building (district, subdistrict and village head), on the other hand, is expected to lead to shared benefits and shared goals by sharing risks, resources and shared responsibilities [5]. While granting authority to develop agroforestry at the farmer and village institution level in the form of functional devolution to form agroforrhea farmers' farmer groups according to local village conditions, is expected to be a means of conflict resolution, as well as an increase in food resilience of small farmers whose lives are highly dependent on forest areas, such as learning experiences gained in Eastern Indonesia in the Mnraleng Maros watershed, South Sulawesi Province of Indonesia [6].

\section{Development of Agroforestry in Owned Areas and Rights to Manage Forest Areas.}

Alternative agroforestry that needs to be developed that is adaptive to climate conditions $\mathrm{C}$ (Schmidth Ferguson classification), as a dry area is an agroforestry model with agrosilviculture and agrosilvopasture patterns. Agrosilviculture model that is adaptive to drought and is able to meet the food needs of the population and can increase population income as a source of weekly, seasonal and annual income, by continuing to grow annual crops such as peanuts and corn, and enriched with annual crops such as coffee, gamal, and mahogany (Table 4).

Table 4. Agroforestry patterns that can be developed in Laubonu Village

\begin{tabular}{|l|l|l|l|l|}
\hline No & $\begin{array}{c}\text { Agroforestry } \\
\text { Patterns }\end{array}$ & $\begin{array}{c}\text { Biophysical } \\
\text { Conditions }\end{array}$ & \multicolumn{1}{|c|}{ Planting Pattern } & \multicolumn{1}{c|}{ Expected Impact } \\
\hline 1. & Agrosilviculture & Flat & $\begin{array}{l}\text { Corn + peanuts + } \\
\text { coffee + gamal + } \\
\text { mahogany } \\
\text { hazelnut }\end{array}$ & $\begin{array}{l}\text { a. Daily food fulfilment. } \\
\text { bour source of weekly, seasonal and } \\
\text { annual income. }\end{array}$ \\
\hline 2. & Agrosilvopasture & $\begin{array}{l}\text { Hilly, } \\
\text { Flat, } \\
\text { Rocky }\end{array}$ & $\begin{array}{l}\text { Coffee + gamal + } \\
\text { mahogany } \\
\text { lamtoro + candlenut } \\
\text { +elephant grass. }\end{array}$ & $\begin{array}{l}\text { a. Annual food fulfillment. } \\
\text { b. Control of encroachment, erosion, and } \\
\text { critical land. } \\
\text { c. Diversification of livelihood sources }\end{array}$ \\
\hline
\end{tabular}


Agrosilvopasture model is expected to be a source of fodder for goats and cattle, besides there are weekly and seasonal sources of income in the presence of coffee plants, while for seasonal and annual products there are goats and candlenuts. For the long term, there is a timber yield from Mahogany stands (Figure ...). The agroforestry model was adapted from the adaptive agroforestry model developed in the Upper Minraleng Watershed, Maros Regency, South Sulawesi Province, Indonesia [7] which has a similar biophysical condition to the Labonu Village of Timor Leste
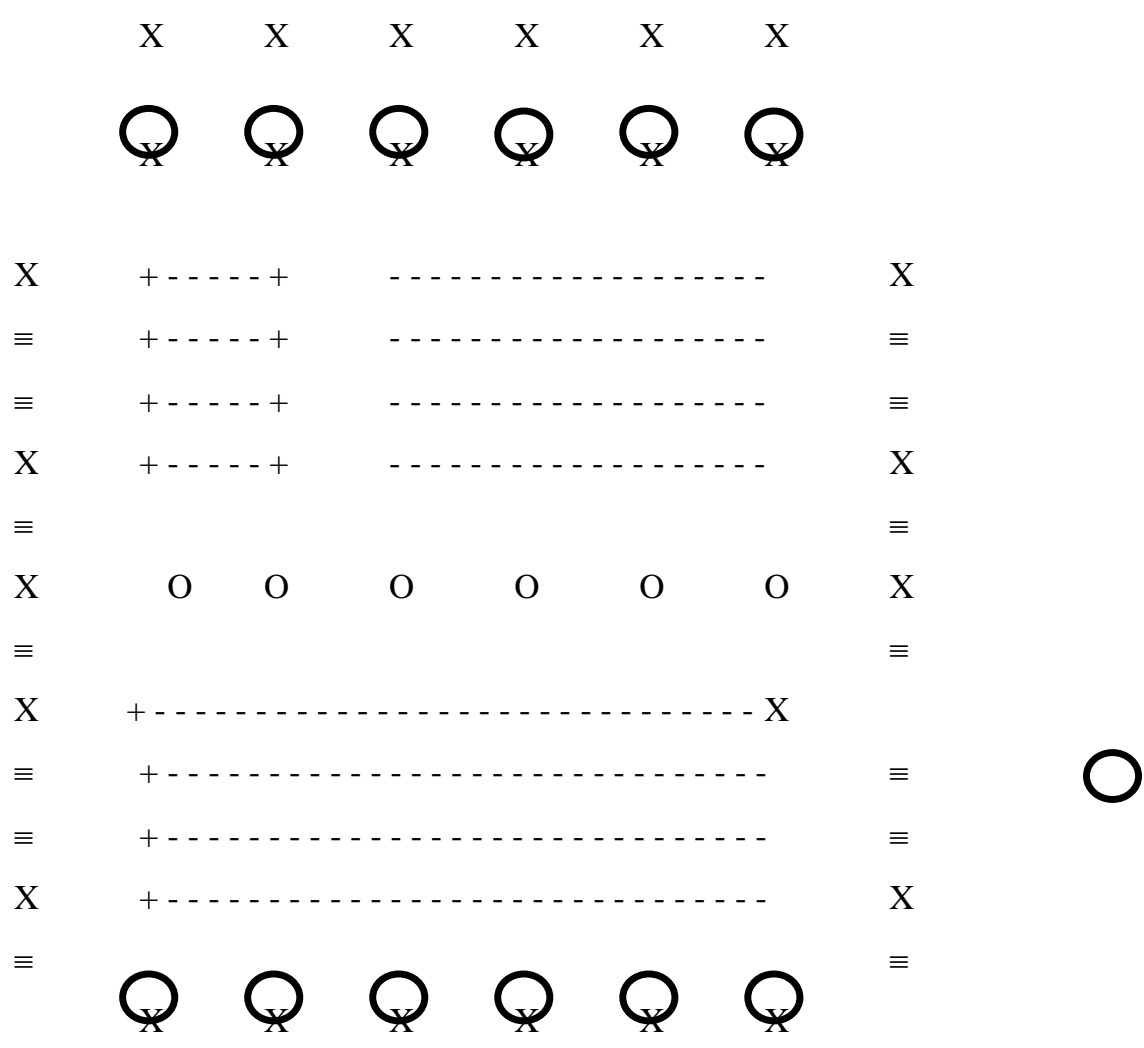

Figure 1. Adaptive Agriculture Model for Agroforestry Development in Laubonu Village

Note: $\mathrm{X}=$ mahogany

$$
\begin{gathered}
\square=\text { gamal } \\
\mathrm{X}=\text { hazelnut } \\
+=\text { corn } \\
---=\text { peanuts } \\
\mathrm{O}=\text { coffee }
\end{gathered}
$$

Based on Table 4 and Figure 1. The form of planting pattern activities that can be carried out is Alternative Strips, namely the combination of two rows of trees and crops as well as livestock crops. Combining crop patterns can be utilized simultaneously without harming anyone plant because it can grow side by side.

Agrosilvopastura development can be done in forest areas and hilly/mountainous areas and river areas or river orders.

\section{CONCLUSION}

Common problems faced by most formal forestry and environmental institutions in Timor Leste, namely: (a). Lack of human resources and the low level of education of formal institutions. (b). Lack of synchronization - program integration in overcoming forest encroachment and illegal logging. (c). The absence of agroforestry models as an alternative to increasing community income while improving the quality of forest area ecosystems in dealing with landslides, forest fires, and increasing critical land, and the absence of policies for the legality of forest area management rights for communities that have long encroached on forest areas (conflicts land).

The agroforestry development model that can be developed in Laubonu Village, namely the agrisilviculture model and the agrosilvopasture model. The Agrosilviculture model is adaptive to drought and is able to meet the food needs of the population and can increase population income as a source of weekly, seasonal and annual income, by continuing to grow annual crops of peanuts, rice and corn, and enriched with annual crops such as coffee, gamal, and mahogany. While the Agrosilvopasture model is expected to be a source of fodder for goats and buffaloes, besides there are weekly and seasonal sources of income in the 
presence of coffee plants, for seasonal and annual income there are a goat and candlenut products. Whereas for the long term, the wood products from Mahogany stand.

3. Agroforestry Development Strategies that can be adopted by the Government of Timor Leste, namely the level of the Ministry of Forestry to form a Working Group (POKJA) for developing Agroforestry (PA). Its main tasks are (1) facilitating the development of regulations (policies and programs) for agroforestry development at pilot sites (2). Facilitating the implementation of the PA Development Program Strengthening Training and briefing for facilitators at the level of directors, district, sub-district and village staff who will socialize and as a facilitator in organizing the agroforestry development program. Facilitators at the district and sub-district, village and field levels are awareness/socialization, formation and strengthening of institutions and preparation of a technical plan for agroforestry development.

\section{REFERENCES}

[1] Mota,F. (2002). Timor Leste: As novas Florestas do Pais. Ministério da Agricultura e Pescas, Direcção Geral de Agricultura, Divisão de Florestas.

[2] Peraturan UNTAET No. 19/2000 Tentang Penetapan Zona Kawasan Lindung Timor-Leste.

[3] Borrini-Feyerabend, Grazia, Farvar, M. T., Nguinguiri, J. C., \& Adangang, V. A. Resources: Organising, Negotiating, and Learning-by-Doing: GTZ and IUCN.

[4] Clarke, A., \& Fuller, M. (2010). Collaborative Strategic Management: Strategy Formulation and Implementation by MultiOrganizational Cross_- Sector Social Partnerships. Journal of Business Ethics, 94, 85-101. doi: 10.1007/s10551-0110781-5

[5] Wolff, T. (2010). The Power of Collaborative Solution: Six Principles and Effective Tool for Building Healthy Communities. San Francisco: Jossey Bass.

[6] Dassir, M., dan A. Sadapotto. 2019. Forestry Devolution Model for the Resilience of Smallholder Livelihood System in the Forest Area of the Eastern Part of Indonesia. IOP Conf.Series : Earth and Environment Science 343 (2019) 012046. doi:10.1088/1755$1315 / 343 / 1 / 012046$

[7] Dassir, M., A. Sadapotto, U. Arsyad, Wahyuni, I. Gautama. 2019. Adaptive Agroforestry Model to Improve Livelihood and to Support the Management of Minraleng Watershed in Maros Regency. IOP Conf.Series:Earth and Environment Science 270 (2019) 012011. doi:10.1088/1755-1315/270/1/012011. 